\title{
TRADE IN TOURISM SERVICES. COMMITMENTS OF NEW EU MEMBER STATES UNDER GATT
}

\section{Michał Kruszka}

\begin{abstract}
One of the core treaties signed by members of the World Trade Organization is General Agreement on Trade in Services (GATS). This is the first multilateral and legally enforceable liberalisation agreement covering trade in services, including tourism, aims to eliminate discriminatory barriers to service trade and increase markets for investment.

The subject of considerable controversy, the GATS has been criticised by human rights, environmental and developing world activist groups, many of whom see it as nothing more than a front for corporate domination of global markets. Supporters, on the other hand, see the GATS potential in overcoming trade disputes and hold out the promise of regional development and employment through increased foreign investment.

This paper aims to outline the GATS, examine its legal principles and explain the enthusiasm of its supporters and the concerns of the critics, especially in the context of situation of new EU members states. Furthermore, it considers the potential impact of the GATS on sustainability tourism.

Ukraine applied for WTO membership in 1993, and the Working Party concluded the negotiations on 25 January 2008 under the chairmanship of Chile's Ambassador Mario Matus. The General Council approved the Working Party report, the market access schedules on goods and services, the General Council Decision and the Protocol of Accession. After several years of economic reforms and multilateral negotiations Ukraine became the WTO's $152^{\text {nd }}$ member on 16 May 2008. It is very important for future Ukraine's economic and trade policy to gather information about past experiences of priors WTO's members concerning the impact of liberalization on tourism
\end{abstract}

Keywords: GATS, tourism JEL classification: F14 